\title{
Effect of Thermocycling On Mechanical and Surface Properties of Three Posterior Restorative Materials
}

\author{
Sinem Akgül(0000-0001-5023-1454) ${ }^{\alpha}$, Ahmet Hazar(0000-0002-7106-0006) ${ }^{\beta}$, İhsan Yıkılgan(0000-0001-5023-1454) ${ }^{\alpha}$, \\ Suat Özcan(0000-0001-6948-6086) ${ }^{\alpha}$, Mine Betül Üçtaşlı(0000-0001-8646-4890) ${ }^{\alpha}$, Oya Bala(0000-0002-7106-0006) ${ }^{\alpha}$
}

Selcuk Dent J, 2021; 8: 352-358 (Doi: 10.15311/selcukdentj.646987)

Başvuru Tarihi: 19 Ağustos 2019 Yayına Kabul Tarihi: 09 Mart 2020

\begin{abstract}
Effect of Thermocycling On Mechanical and Surface Properties of Three Posterior Restorative Materials

Background: To evaluate the mechanical and surface properties of two glass ionomer restorative systems (EQUIA Fil, lonostar Molar) and a resin composite (Charisma Classic) after thermocycling.

Methods: Twenty disk-shaped samples were prepared from each material in teflon molds according to manufacturer's instructions. After the samples were stored in distilled water at $37^{\circ} \mathrm{C}$ for $24 \mathrm{~h}$, microhardness and surface roughness measurements were performed from each group and repeated after 5000 and 10000 thermocycling. Scanning electron microscopy examinations were also performed. The data were analyzed by using Wilcoxon signed rank and Bonferroni corrected multiple comparison tests.
\end{abstract}

Results: EQUIA did not exhibit significant differences in its microhardness values after thermocycling $(p>0.005)$. In contrast, Ionostar Molar and Charisma Classic exhibited statistically significant decreases in baseline microhardness after 5000 and 10000 thermocycling processes (both $p<0.005$ ). However, there were no significant differences between 5000 and 10000 thermocycling groups for Charisma Classic $(p=0.007)$. Ionostar Molar exhibited no statistically significant differences between its surface roughness values before and after thermocycling groups $(p=0.067)$. Similarly, there were no significant differences between baseline and 5000 thermocycling groups for EQUIA and Charisma Classic $(p>0.05)$. However, a statistically significant increase was observed after 10000 thermocycles for both of these two materials $(p=0.002$ and $p<0.001$, respectively).

Conclusion: The EQUIA and lonostar Molar exhibited mechanical features similar to those of a resin composite, and thus, represent promising materials for permanent restorations.

\section{KEYWORDS}

Glass ionomer, Scanning electron microscopy, Surface properties

Recently, greater diversity has been developed among commercially available dental restorative materials in response to an increased number of aesthetic requests. ${ }^{1}$ In particular, glass ionomer cements (GICs), which were identified at the end of the 1960s by Wilson and Kent, are currently widely used in clinical dentistry. ${ }^{2}$ Conventional GICs were previously bonded to tooth structures without adhesives. The advantages of this approach include biocompatibility, low cytotoxicity, fluoride release, and good marginal adaptation. ${ }^{3,4}$

\section{öz}

Isıl Döngü Ile Yaşlandırmanın Üç Posterior Restoratif Materyalin Mekanik Ve Yüzey Özellikleri Üzerine Etkisi

Amaç: İki cam iyonomer restoratif sistem (EQUA Fil, lonostar Molar) ve bir kompozit rezinin ısıl döngü ile yaşlandırma sonrası mekanik ve yüzey özelliklerini değerlendirmektir.

Gereç ve Yöntemler: Her materyalden 20 adet örnek üretici firma talimatları doğrultusunda hazırlandı. Örnekler $37^{\circ} \mathrm{C}$ 'de 24 saat bekletildikten sonra, mikrosertlik ve yüzey pürüzlülük ölçümleri yapıldı ve bu ölçümler 5000 ve 10000 ısıl döngü sonrasında tekrarlandı. Her gruptan bir örnek yüzey değerlendirmesi için taramalı elektron mikroskobisi ile incelendi. Veriler Wilcoxon signed rank testi ve Bonferroni düzeltmeli çoklu karşılaştırma testi kullanılarak analiz edildi.

Bulgular: EQUIA, ısıl döngü sonrası mikrosertlik değerlerinde anlamlı bir farklılık göstermedi $(p>0.005)$. Ionostar Molar ve Charisma Classic gruplarında başlangıç mikrosertlik değerlerine göre 5000 ve 10000 ısıl döngü sonrası anlamlı azalma gözlendi $(p<0.005)$. Ancak 5000 ve 10000 döngü değerlendirmeleri arasında ise Charisma Classic grubunda anlamlı farklılık tespit edilmedi $(p=0.007)$. lonostar Molar yüzey pürüzlülük ölçümlerinde ısıl döngü öncesi ve sonrasında anlamlı farklılık gözlenmedi $(p=0.067)$. EQUIA ve Charisma Classic gruplarında ise başlangıç ve 5000 ısıl döngü sonrası grupları arasında farklılık bulunmadı $(p>0.05)$. Bununla beraber, her iki materyalde de 10000 döngü sonrası yüzey pürüzlülük değerlerinde anlamlı bir azalma tespit edildi $(p=0.002, p<0.001$, sırasıyla).

Sonuç: EQUIA ve lonostar Molar mekanik özellikleri yönünde kompozit rezine yaklaşabilecek özellikler göstermiştir bu sebeple daimi restorasyonlarda umut verici materyaller olabilirler.

\section{ANAHTAR KELIMELER}

Cam iyonomer, Tarama elektron mikroskobisi, Yüzey özellikleri

However, they have some disadvantages such as prolonged setting time, moisture sensitivity during initial setting, dehydration, and rough surface texture. Additionally, GICs are reported as low fracture toughness and higher occlusal wear than the other restorative materials such as amalgam and composite resin. ${ }^{5,6}$

More recently, to overcome these shortcomings, the mechanical properties of conventional GICs have been

\footnotetext{
${ }^{\alpha}$ Gazi University Faculty of Dentistry Department of Restorative Dentistry Ankara, Turkey

$\beta$ Bülent Ecevit University Faculty of Dentistry Department of Restorative Dentistry Zonguldak, Turkey
} 
modified with the addition of various fillers, ultrafine and highly reactive glass particules, that increase the viscosity of these cements. ${ }^{7,8}$ These modifications also enhance mechanical properties and improve wear resistance of materials in comparison with the traditional GICs. ${ }^{9}$ As a result, these GICs have been widely used as a permanent restorative material. A further innovation has been the development of a restorative system that consists of a highly viscous GIC combined with a nanofilled coating material called Eqiua. This resin-based coating provides a perfect seal and increases wear resistance, while also improving the aesthetic properties of this system.1,10,11 Another product with similar features, Ionostar Molar consists of a physically reinforced GIC, a nanofilled coating material and in an easy manipulation form. ${ }^{12}$ However, there is not yet enough evidence about the physical properties of both restorative systems.

It has been reported that reinforced GICs exhibit improved physical and mechanical properties compared with conventional GICs. ${ }^{13,14}$ Some of the properties that have been evaluated in characterizations of GICs are comprehensive stress, microhardness, fracture toughness, creep and wear rate. ${ }^{15-17}$

When a restorative material exposed to the oral environment for a long time, some changes occur in its aesthetic properties such as staining, plaque accumulation, gingival irritation and discoloration. ${ }^{18}$ Restorations are also exposed to thermal stresses during normal oral functions. Thermal stresses disrupt the structure of restorative materials and may adversely affect their mechanical properties. In many studies, the effects of thermal stresses on restorative materials have been examined. ${ }^{18,19}$

Scanning electron microscopy (SEM) is another effective method for evaluating the surface topography, filler amount, size, and interface of restorations. SEM is particularly recommended for evaluating the types of failures that restorations undergo, as well as surface alterations and wear. ${ }^{20,21}$ While the surface properties of GICs have been evaluated with $\mathrm{SEM}^{22,23}$, studies about reinforced glass ionomer restorative systems are limited. ${ }^{24}$

Therefore, the aim of this in vitro study was to evaluate the mechanical and surface properties of two high viscosity, resin-coated glass ionomer restorative systems, EQUIA Fil (GC, Japan) and Ionostar Molar (Voco, Germany), as well as a microhybrid posterior resin composite, Charisma Classic (Heraus Kulzer, Germany), after thermocycling process.

\section{MATERIALS AND METHODS}

\section{Sample preparation}

Two reinforced glass ionomer restorative systems and a microhybrid resin composite (included as a positive control) were evaluated in this study (Table 1).

Table 1.

\section{The type and composition of the tested materials}

\begin{tabular}{|c|c|c|c|}
\hline Material & Manufacturer & Type & Composition \\
\hline \multirow[b]{2}{*}{ EQUIA } & \multirow[b]{2}{*}{$\begin{array}{l}\text { GC, Tokyo, } \\
\text { Japan }\end{array}$} & \multirow[b]{2}{*}{ Highly viscous GIC } & $\begin{array}{l}\text { Powder: Strontium } \\
\text { fluoroalumino-silicate glass }\end{array}$ \\
\hline & & & $\begin{array}{l}\text { Liquid: Aqueous polyacrylic } \\
\text { acid, polybasic carboxylic acid, } \\
\text { water }\end{array}$ \\
\hline EQUIA Coat & $\begin{array}{l}\text { GC, Tokyo, } \\
\text { Japan }\end{array}$ & $\begin{array}{l}\text { Low-viscosity } \\
\text { nanofilled surface } \\
\text { coating resin }\end{array}$ & $\begin{array}{l}\text { Methyl methacrylate, colloidal } \\
\text { silica, camphoquinone, } \\
\text { urethane methacrylate, } \\
\text { phosphoric ester monomer }\end{array}$ \\
\hline \multirow{2}{*}{$\begin{array}{l}\text { lonostar } \\
\text { Molar }\end{array}$} & \multirow{2}{*}{$\begin{array}{l}\text { Voco, } \\
\text { Cuxhaven, } \\
\text { Germany }\end{array}$} & \multirow{2}{*}{ Highly viscous GIC } & $\begin{array}{l}\text { Powder: Fluoroalumino-silicate } \\
\text { glass, }\end{array}$ \\
\hline & & & Liquid: Polyacrylic acid, \\
\hline $\begin{array}{l}\text { Final Varnish } \\
\text { LC }\end{array}$ & $\begin{array}{l}\text { Voco, } \\
\text { Cuxhaven, } \\
\text { Germany }\end{array}$ & $\begin{array}{l}\text { Low-viscosity } \\
\text { nanofilled surface } \\
\text { coating resin }\end{array}$ & $\begin{array}{l}\text { Bis-GMA, Diurethane } \\
\text { dimethacrylate, HEDMA, } \\
\text { Catalyst }\end{array}$ \\
\hline $\begin{array}{l}\text { Charisma } \\
\text { Classic }\end{array}$ & $\begin{array}{l}\text { Heraus Kulzer, } \\
\text { Germany }\end{array}$ & $\begin{array}{l}\text { Microhybrid resin } \\
\text { composite }\end{array}$ & $\begin{array}{l}\text { Bis-GMA, TEGDMA, Ba-Al-F } \\
\text { glass, } \mathrm{SiO}_{2}\end{array}$ \\
\hline
\end{tabular}

To prepare samples for analysis, restorative materials were placed in teflon molds with a diameter of $5 \mathrm{~mm}$ and a depth of $2 \mathrm{~mm}$ and then were prepared according to each manufacturer's instructions. Initially, each mold was mounted on top of a mylar strip and a glass plate. The mylar strip was positioned on the mold and another glass plate was placed on top of the filled mold. A slight pressure was applied to obtain a standard thickness and surface. For the resin composite group, the samples were cured for $20 \mathrm{~s}$ with a LED light curing unit (G Light, GC, Japan) with $1000 \mathrm{~mW} / \mathrm{cm}$ intensity. For the glass ionomer samples, after the self-polymerization process was completed, the mylar strips were discarded and surface coating agents were applied and light cured for $20 \mathrm{~s}$. The samples were then stored in distilled water at $37{ }^{\circ} \mathrm{C}$ for $24 \mathrm{~h}$. Twenty samples were prepared from each material.

\section{Microhardness measurements}

Ten samples from each of the material groups were subjected to microhardness tests. A Vicker's hardness number $(\mathrm{VHN})\left(\mathrm{kg} / \mathrm{mm}^{2}\right)$ was determined for each sample prior to thermocycling by using a microhardness tester (Shimadzu HMV-2, Japan). Three indentations were made on the top of each surface with application of a $50 \mathrm{~g}$ load for a $15 \mathrm{~s}$ dwell time and an average microhardness value was 
determined for each sample. The samples were subsequently immersed in a water bath and thermocycled 5000 times between $5{ }^{\circ} \mathrm{C}$ and $55^{\circ} \mathrm{C}$ with a dwelling time of $15 \mathrm{~s}$ in each bath (MTE 101 Thermocycling Machine, Esetron, Turkey). The measurements were performed again. Thermocycling was then repeated an additional 5000 times and microhardness measurements were repeated as described above.

\section{Surface roughness measurements}

Ten samples from each material group were evaluated. Briefly, a profilometer was applied to three different points on the top of each surface (Surfest SJ-301 Mitutoyo Japan) and an average surface roughness value was determined for each sample. The measurements were repeated after the first and subsequent 5000 thermocycling processes.

\section{SEM evaluation}

One sample from each group was prepared for examination by SEM. Briefly, after the samples were dehydrated, they were gold-sputtered and examined at 1000X magnification. SEM evaluations were performed after both thermocycling processes.

\section{Statistical analysis}

Mean \pm standard deviation (SD) values were estimated. The Wilcoxon signed rank and Bonferroni corrected multiple comparison tests were used to analyze alterations in the surface properties of the prepared samples after thermocycling.

\section{RESULTS}

\section{Microhardness evaluation}

Mean $\mathrm{VHN} \pm \mathrm{SD}$ values are reported for the tested restorative materials before and after the 5000 and 10000 thermocycling processes at Table 2.

Table 2.

After $24 \mathrm{~h}$ and after thermocycling microhardness values (mean \pm standard deviation) of the tested materials

\begin{tabular}{|c|c|c|c|}
\hline Material & $\begin{array}{l}\text { After } 24 \mathrm{~h} \text { of } \\
\text { preparation }\end{array}$ & $\begin{array}{l}\text { After } 5000 \\
\text { thermocycling }\end{array}$ & $\begin{array}{l}\text { After } 10000 \\
\text { thermocycling }\end{array}$ \\
\hline EQUIA & $26.09 \pm 1.37^{\mathrm{a}}$ & $25.13 \pm 1.30^{\mathrm{a}}$ & $24.52 \pm 1.90^{\mathrm{a}}$ \\
\hline Ionostar Molar & $22.19 \pm 1.10^{b}$ & $20.33 \pm 0.83^{c}$ & $19.04 \pm 1.20^{d}$ \\
\hline Charisma Classic & $65.71 \pm 2.06^{\circ}$ & $63.19 \pm 1.57^{4}$ & $61.51 \pm 1.83^{t}$ \\
\hline
\end{tabular}

In each row, values with different superscript letters indicate significant differences $(p<0.005)$ whereas same superscript letters indicate no significance differences $(p>0.005)$

According to the Wilcoxon signed rank test, the EQUIA material did not exhibit a significant difference after either thermocycling process $(p>0.005)$. In contrast, the lonostar Molar and Charisma Classic materials exhibited statistically significant decreases in their VHN values after both the 5000 and 10000 thermocycling processes compared with the VHN value at baseline (each $\mathrm{p}<0.005)$. For the microhybrid resin composite group, there were no significant differences between the 5000 and 10000 thermocycling samples $(p=0.007)$.

\section{Surface roughness evaluation}

Mean surface roughness $\pm S D$ values for the tested restorative materials before and after the thermocycling processes are reported at Table 3.

\section{Table 3.}

After $24 \mathrm{~h}$ and after thermocycling surface roughness values (mean \pm standard deviations) of the tested materials

\begin{tabular}{|c|c|c|c|}
\hline Material & $\begin{array}{l}\text { After } 24 \mathrm{~h} \text { of } \\
\text { preparation }\end{array}$ & $\begin{array}{c}\text { After } 5000 \\
\text { thermocycling }\end{array}$ & $\begin{array}{l}\text { After } 10000 \\
\text { thermocycling }\end{array}$ \\
\hline EQUIA & $0.15 \pm 0.07^{\mathrm{a}}$ & $0.17 \pm 0.06^{\mathrm{a}, \mathrm{b}}$ & $0.19 \pm 0.08^{b}$ \\
\hline Ionostar Molar & $0.15 \pm 0.04^{\circ}$ & $0.21 \pm 0.06^{c}$ & $0.21 \pm 0.06^{c}$ \\
\hline Charisma Classic & $0.10 \pm 0.05^{d}$ & $0.17 \pm 0.05^{\mathrm{d}, \mathrm{e}}$ & $0.19 \pm 0.07^{e}$ \\
\hline
\end{tabular}

*In each row, values with different superscript letters indicate significant differences $(p<0.005)$ whereas same superscript letters indicate no significance differences $(p>0.005)$.

According to the Bonferroni correction multiple comparison test, The lonostar Molar material exhibited no statistically significant differences in surface roughness values before and after the thermocycling processes ( $p>0.067$ ). Similarly, there were no significant differences between the surface roughness values at baseline and after 5000 cycles for the EQUIA and Charisma Classic materials $(p=071$ and $p>0.029$, respectively). However, a statistically significant surface alteration was observed between baseline and after the 10000 cycle thermocycling process for both materials $(p=0.002$ and $p<0.001$, respectively).

\section{SEM evaluation}

Representative SEM photomicrographs of all of the tested materials are shown in Figure 1. Topographically, there were no apparent differences in the surfaces of the Charisma Classic resin after thermocycling. In contrast, there were large cracks and ruptures in the surface of the EQUIA samples after thermocycling, while only partial surface alterations such as little and superficial degradations were observed for the lonostar Molar samples. 


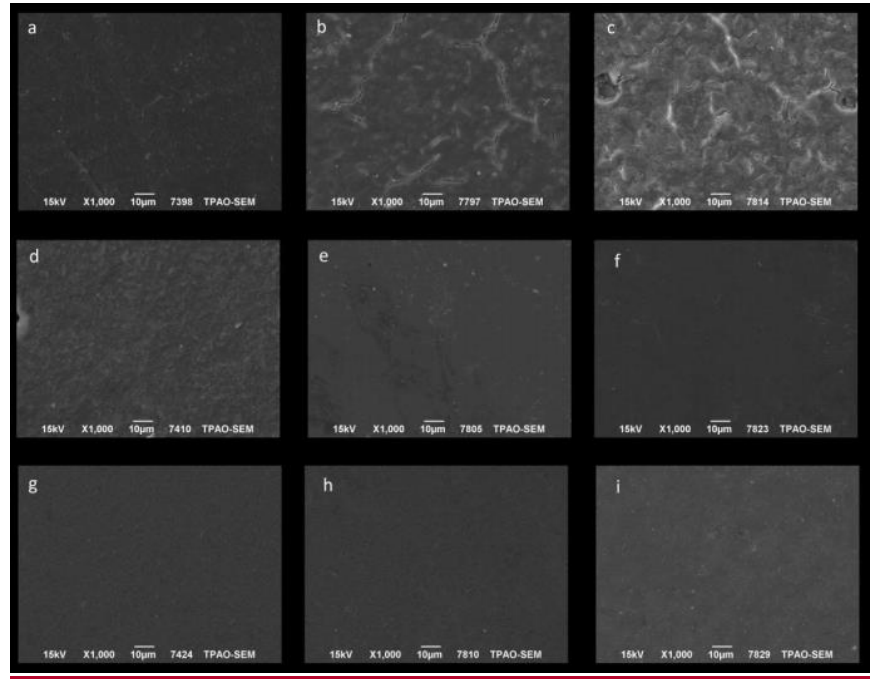

Figure 1

SEM microphotographs of tested materials. (a) EQUIA before thermocycling, (b) EQUIA after 5000 thermocycling, (c) EQUIA after 10000 thermocycling, (d) Ionostar Molar before thermocycling, (e) Ionostar Molar after 5000 thermocycling, (f) Ionostar Molar after 10000 thermocycling, (g) Charisma Classic before thermocycling, (h) Charisma Clasic after 5000 thermocycling, (i) Charisma Classic after 10000 thermocycling

\section{DISCUSSION}

GICs are widely used as permanent restorative materials due to their physical and mechanical properties. By the end of the 1990s, highly viscous GICs had been developed which were characterized by an easy application method and high mechanical properties. ${ }^{25}$ In addition, nanofilled resin coatings were developed to enhance the longevity and wear resistance of GICs. ${ }^{11}$ The aim of this in vitro study was to evaluate the microhardness and surface properties of two more recently developed highly viscous glass ionomer restorative systems, EQUIA and Ionostar Molar, and to compare these properties with those of a microhybrid-filled resin composite, Charisma Classic.

In general, the setting process for GICs is based on an acid-base reaction that occurs between a polyacid liquid and glass powder over several weeks. ${ }^{26}$ The reaction begins immediately upon mixing and precipitation of the cement occurs within the first 3-6 min after mixing. Consequently, moisture contamination of these restorative materials is an important consideration for the clinical conditions of this process. $^{5}$ Gemalmaz et al. observed that early moisture contamination decreased the mechanical properties of GICs and affected surface alterations in the restorations. ${ }^{27}$ The application of resin coating for GICs is a widespread protective approach. Resinbased coating materials prevent early moisture contamination that improves the mechanical and surface properties of GICs which play an important role in the clinical survival of the restorations. Several in vitro studies have demonstrated the positive effect of these coating materials on the mechanical characteristics of GICs. ${ }^{28-30}$
Thermocycling is an aging procedure that imitates rapid thermal changes in order to evaluate hydrolytic and thermal alterations that occur in materials. ${ }^{31}$ To mimic the oral environment after a period of 6 months or 12 months, 5000 and 10000 thermocycles, respectively, have been applied ${ }^{32}$ and were also applied in the present study. The application of this aging process to evaluate the surface properties of resin-based restorative materials was also previously demonstrated. ${ }^{33}$ In the current study, the mean microhardness and surface roughness values of the resin composite tested significantly decreased after thermocycling. A similar result was achieved by Tuncer et al. with the application of 10000 thermocycles to other resin composites. ${ }^{34}$ Meanwhile, the lonostar Molar had significantly lower microhardness values after thermocycling, while the EQUIA exhibited no significant difference. When the EQUIA material was compared with zinc-reinforced GICs in a previous study, higher microhardness values were observed. ${ }^{35}$ In another study, application of the EQUIA material with a surface coating resulted in higher microhardness values after aging compared with other restorative materials. ${ }^{36}$ Given that EQUIA is reinforced with strontium, this property may explain these results.

In the present study, resin-based coating agents were applied to the surfaces of both of the GICs that were examined according to the manufacturer's directions. In previous studies, it was observed that resin-based coating agents that were applied to GICs surfaces enhanced the mechanical properties of the materials. $^{37,38}$ The resin components of the surface coating agents used in the present study differed from those previously used, and this may be the reason for the difference in microhardness values between the GIC groups in this study and those of other studies. It is known that the application of Final Varnish LC to the lonostar Molar material is predisposed to water absorption due to the presence of Bis-GMA in the former ${ }^{39}$ and absorption of water can lead to weakening of polymer structures and deterioration at the interface between the matrix and filler. ${ }^{40}$

When defining "surface quality", properties such as roughness, color, gloss, and morphology have been evaluated. ${ }^{41}$ Surface roughness is a clinically important factor due to its retention potential of dental plaque and its increased risk of secondary caries. ${ }^{42}$ Furthermore, previous studies have reported that the surface roughness of GICs is affected by filler size, shape, amount, distribution of particles in the matrix, and liquid content. ${ }^{43,44}$

In the current study, the lonostar Molar samples exhibited no significant surface alterations after thermocycling, while the EQUIA samples exhibited significant surface alterations after 10000 thermocycles. The coating agent in the former was Final Varnish with Bis-GMA and was G-Coat Plus with methyl methacrylate 
methacrylate (MMA) in the latter. When Zang et al. evaluated water solubility of monomers in relation to the degree of conversion for resin materials, the mobility and water solubility of Bis-GMA were found to be reduced compared with MMA due to particle size. ${ }^{45}$ Furthermore, high water solubility of a component in a material can adversely affect the surface properties of restorations. ${ }^{46}$ These findings are compatible with the present observations where coating of EQUIA with an MMA-containing coating agent resulted in significantly greater surface alterations after thermocycling. Correspondingly, in SEM photomicrographs, large cracks and ruptures were observed at the surface of the EQUIA samples after 10000 thermocycles, and this is attributed to the colloidal silica component of the coating agent that broke away from the surface over time. Moreover, it is possible that the remaining filler particles could have influenced the observed surface alterations of EQUIA as well. EQUIA' surface roughness values weren't compatible with SEM images, but this may be related to the examining only one sample from each group and evaluated a limited and small area in SEM imaging. Additionally, in lonostar Molar's SEM images, there was only small surface degradations were observed in accordance with the surface roughness values.

\section{CONCLUSION}

Within the limitations of this in vitro study,

1. The surface properties of the GICs were found to be lower than those of the resin composite.

2. Application of thermocycling as an in vitro aging procedure may have influenced the mechanical properties of the GIC restorations.

3. The SEM images obtained showed significant alterations had occurred at the surface of the EQUIA samples after thermocycling. 


\section{REFERENCES}

1. Gurgan S, Kutuk ZB, Ergin E, Oztas SS, Cakir FY. Fouryear randomized clinical trial to evaluate the clinical performance of a glass ionomer restorative system. Oper Dent. 2015;40(2):134-43.

2. Wilson $A D$, Kent $B E$. $A$ new translucent cement for dentistry. The glass ionomer cement. $\mathrm{Br}$ Dent $\mathrm{J}$. 1972;132(4):133-5.

3. Costa CA, Ribeiro AP, Giro EM, Randall RC, Hebling J.. Pulp response after application of two resin modified glass ionomer cements (RMGICs) in deep cavities of prepared human teeth. Dent Mater. 2011;27(7):e158-70.

4. Cehreli SB, Tirali RE, Yalcinkaya Z, Cehreli ZC.. Microleakage of newly developed glass carbomer cement in primary teeth. European journal of dentistry. 2013;7(1):15-21.

5. Naasan MA, Watson TF. Conventional glass ionomers as posterior restorations. A status report for the American Journal of Dentistry. Am $J$ Dent. 1998;11(1):36-45.

6. Ilie N, Hickel R, Valceanu AS, Huth KC. Fracture toughness of dental restorative materials. Clin Oral Investig. 2012;16(2):489-98.

7. Gjorgievska E, Van Tendeloo G, Nicholson JW, Coleman NJ, Slipper IJ, Booth S. The incorporation of nanoparticles into conventional glass-ionomer dental restorative cements. Microsc Microanal. 2015;21(2):392406.

8. Moshaverinia M, Navas A, Jahedmanesh N, Shah KC, Moshaverinia A, Ansari S. Comparative evaluation of the physical properties of a reinforced glass ionomer dental restorative material. J Prosthet Dent. 2019;122(2):154-9.

9. Forte GAE. EQUIA Forte Bulk Fill,fluoride releasing, glass hybrid restorative system. 2019.October.15 [Available http://www.gcamerica.com/products/operatory/EQUIA Forte/.

10.Davidson CL. Advances in glass-ionomer cements. J Appl Oral Sci. 2006;14 Suppl:3-9.

11.Diem VTK, Tyas MJ, Ngo HC, Phuong LH, Khanh ND. The effect of a nano-filled resin coating on the 3-year clinical performance of a conventional high-viscosity glass-ionomer cement. Clinical oral investigations. 2014;18(3):753-9.

12.Collado-González M, Pecci-Lloret MR, Tomás-Catalá $\mathrm{CJ}$, et al. Thermo-setting glass ionomer cements promote variable biological responses of human dental pulp stem cells. Dental Materials. 2018;34(6):932-43.

13.13. Wilson AD. Resin-modified glass-ionomer cements. International Journal of Prosthodontics. 1990;3(5).

14. McLean JW. The clinical use of glass-ionomer cements. Dent Clin North Am. 1992;36(3):693-711.

15. Goldman M. Fracture properties of composite and glass ionomer dental restorative materials. Journal of biomedical materials research. 1985;19(7):771-83.
16. Cattani-Lorente MA, Godin C, Meyer JM. Mechanical behavior of glass ionomer cements affected by long-term storage in water. Dent Mater. 1994;10(1):37-44.

17.Papadogiannis $Y$, Helvatjoglou-Antoniadi $M$, Lakes $\mathrm{R}$, et al. The creep behavior of glassionomer restorative materials. Dental Materials. 1991;7(1):40-3.

18. Minami $\mathrm{H}$, Hori $\mathrm{S}$, Kurashige $\mathrm{H}$, et al. Effects of thermal cycling on surface texture of restorative composite materials. Dental materials journal. 2007;26(3):316-22.

19. Morresi AL, D'Amario M, Monaco A, et al. Effects of critical thermal cycling on the flexural strength of resin composites. J Oral Sci. 2015;57(2):13743.

20. Hirt T, Lutz F, Roulet JF. In vivo evaluation of occlusal wear of two experimental composites versus amalgam. Journal of oral rehabilitation. 1984;11(6):511-20.

21.Sulong MZ, Aziz RA. Wear of materials used in dentistry: a review of the literature. J Prosthet Dent. 1990;63(3):342-9.

22. Mueller $\mathrm{HJ}$. Fracture toughness and fractography of dental cements, lining, build-up, and filling materials. Scanning microscopy. 1990;4(2):297-307.

23.桃井保子, 広崎国継, 河野篤, et al. Flexural properties of resin-modified "hybrid" glassionomers in comparison with conventional acidbase glass-ionomers. Dental Materials Journal. 1995;14(2):109-19,275.

24.Dionysopoulos D, Tolidis $K$, Sfeikos $T$, et al. Evaluation of Surface Microhardness and Abrasion Resistance of Two Dental Glass lonomer Cement Materials after Radiant Heat Treatment. Advances in Materials Science and Engineering. 2017;2017.

25.Tyas MJ. Clinical evaluation of glass-ionomer cement restorations. Journal of Applied Oral Science. 2006;14(SPE):10-3.

26. Crisp S, Lewis B, Wilson A. Characterization of glass-ionomer cements 1 . Long term hardness and compressive strength. Journal of Dentistry. 1976;4(4):162-6.

27. Gemalmaz D, Yoruc B, Ozcan M, et al. Effect of early water contact on solubility of glass ionomer luting cements. The Journal of prosthetic dentistry. 1998;80(4):474-8.

28. Lohbauer U, Krämer N, Siedschlag $G$, et al. Strength and wear resistance of a dental glassionomer cement with a novel nanofilled resin coating. American journal of dentistry. 2011;24(2):124-8.

29. Aljamhan A, Platt J, Cook N, et al. Resin-coated glass ionomer cement abrasion and wear resistance. Journal of Dental Research. 2012;91. 
30.Bagheri R. Effect of G-Coat Plus on the properties of aesthetic restorations. Journal of Dental Research. 2012;91.

31.Ernst C-P, Canbek K, Euler T, et al. In vivo validation of the historical in vitro thermocycling temperature range for dental materials testing. Clinical oral investigations. 2004;8(3):130-8.

32. Gale $M$, Darvell B. Thermal cycling procedures for laboratory testing of dental restorations. Journal of dentistry. 1999;27(2):89-99.

33. Barcellos DC, Pucci CR, Torres CRG, et al. Effects of resinous monomers used in restorative dental modeling on the cohesive strength of composite resin. Journal of Adhesive Dentistry. 2008;10(5).

34.Tuncer S, Demirci M, Tiryaki $M$, et al. The effect of a modeling resin and thermocycling on the surface hardness, roughness, and color of different resin composites. Journal of Esthetic and Restorative Dentistry. 2013;25(6):404-19.

35.Al-Angari SS, Hara AT, Chu T-M, et al. Physicomechanical properties of a zinc-reinforced glass ionomer restorative material. Journal of oral science. 2014;56(1):11-6.

36.Zoergiebel J, Ilie N. Evaluation of a conventional glass ionomer cement with new zinc formulation: effect of coating, aging and storage agents. Clinical oral investigations. 2013;17(2):619-26.

37. Holmgren CJ, Figueredo MC. Two decades of ART: improving on success through further research. Journal of Applied Oral Science. 2009;17(SPE):122-33.

38. Koenraads $H$, Van der Kroon G, Frencken J. Compressive strength of two newly developed glassionomer materials for use with the Atraumatic Restorative Treatment (ART) approach in class II cavities. dental materials. 2009;25(4):551-6.

39. Cornelio RB, Wikant $A$, Mjøsund $H$, et al. The influence of bis-EMA vs bis GMA on the degree of conversion and water susceptibility of experimental composite materials. Acta Odontologica Scandinavica. 2014;72(6):440-7.

40.Souza RO, Özcan M, Michida SM, et al. Conversion degree of indirect resin composites and effect of thermocycling on their physical properties. Journal of Prosthodontics: Implant, Esthetic and Reconstructive Dentistry. 2010;19(3):218-25.

41. Kakaboura A, Fragouli M, Rahiotis C, et al. Evaluation of surface characteristics of dental composites using profilometry, scanning electron, atomic force microscopy and gloss-meter. Journal of Materials Science: Materials in Medicine. 2007;18(1):155-63.

42. Tanoue $N$, Matsumura $H$, Atsuta $M$, et al. Wear and surface roughness of current prosthetic composites after toothbrush/dentifrice abrasion. The Journal of prosthetic dentistry. 2000;84(1):93-7.

43. Bala O, Arisu HD, Yikilgan I, et al. Evaluation of surface roughness and hardness of different glass ionomer cements. European journal of dentistry. 2012;6(1):79.
44.Raggio DP, Bonifácio CC, Bönecker $\mathrm{M}$, et al. Effect of insertion method on knoop hardness of high viscous glass ionomer cements. Brazilian dental journal. 2010;21(5):439-45.

45.Zhang M, Puska MA, Botelho MG, et al. Degree of conversion and leached monomers of urethane dimethacrylate-hydroxypropyl methacrylate-based dental resin systems. Journal of oral science. 2016;58(1):15-22.

46. Øysæd H, Ruyter I. Water sorption and filler characteristics of composites for use in posterior teeth. Journal of dental research. 1986;65(11):1315-8.

\section{Corresponding Author:}

Sinem AKGUL

Gazi University Faculty of Dentistry

Department Restorative Dentistry,

Ankara, Turkey

Phone : +90312 2034399

E-mail :sinemakipek@gmail.com 